\title{
EVALUATION OF WOMEN'S BELIEFS ABOUT PAP SMEAR SCREENING USING THE HEALTH BELIEF MODEL SCALE
}

\author{
KADINLARIN PAP SMEAR TARAMASINA ILIŞKIN INANÇLARININ SAĞLIK INANÇ \\ MODELI ÖLÇEĞi ILE DEĞERLENDIRILMESi
}

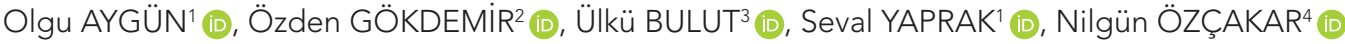 \\ ${ }^{1} T$ The Ministry of Health, İzmit County Health Directorate, İzmit, Turkey \\ ${ }^{2}$ Izmir University of Economics, Faculty of Medicine, Basic Medical Sciences, Izmir, Turkey \\ ${ }^{3}$ Aksaray University, Faculty of Medicine, Department of Family Medicine, Aksaray, Turkey \\ ${ }^{4}$ Dokuz Eylul University, Faculty of Medicine, Department of Family Medicine, Izmir, Turkey
}

ORCID IDs of the authors: O.A. 0000-0002-9767-011X; Ö.G. 0000-0002-0542-5767; Ü.B. 0000-0003-3011-0924; S.Y. 0000-0002-1454-1612; N.Ö. 0000-0003-0434-214X

Cite this article as: Aygun O, Gokdemir O, Bulut U, Yaprak S, Ozcakar N. Evaluation of women's beliefs about pap smear screening using the health belief model scale. J Ist Faculty Med 2020;83(4):421-6. doi: 10.26650/IUITFD.2020.0023

\section{ABSTRACT}

Objective: To evaluate women's beliefs about screening Pap smear test.

Material and Method: The survey has been conducted through a questionnaire prepared by researchers, based on the Health Belief Model Scale for the Pap smear test. The participants consisted of 266 women between 18-70 years of age registered at a Family Health Center in Izmir. Their beliefs about screening Pap smear test were evaluated using the Health Belief Model Scale.

Results: The mean age of first sexual intercourse was $21.67 \pm 4.5$ (min:13--max:45 years), 86.5\% reported a single partner and $41.0 \%$ of them $(n=109)$ had never undergone a Pap smear test. Women who previously had a Pap smear test had high scores of sensitivity, seriousness, advantage and motivation, health motivation subscales, but the mean scores for obstacles were low. There was a difference between seriousness, health motivation subscales and taking the Pap smear test $(p=0.021, p=0.006)$. The Mean scores of seriousness and health motivation of Health Belief Model Scale were higher. There was no difference between education level, working status and undergoing a Pap test (p>0.05)

Conclusion: Having a Pap smear test is still moderately frequent and there are obstacles. Planning the interventions to eliminate Pap smear test barriers is an important issue for family physicians.

Keywords: Health behaviour, health belief, cervical smear

\section{ÖZET}

Amaç: Bu çalışmanın amacı kadınların Pap smear test taramasına ilişkin inançlarını değerlendirmektir.

Gereç ve Yöntem: Araştırma, araştırmacı tarafından geliştirilen Pap smear testi için Sağlık İnanç Modeli Ölçeğini içeren bir anket aracılığıyla gerçekleştirilmiştir. Katılımcılar, İzmir'de bir Aile Sağlığı Merkezi'ne kayıtlı 18-70 yaş arası 266 kadındı. Pap smear testi taramasına ilişkin inançları Sağlık Inanç Modeli Ölçeği kullanılarak değerlendirildi.

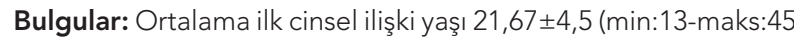
yıl) idi, \%86,5'i tek partner olduğunu ve \%41,0'ı ( $n=109)$ hiç Pap smear testi yaptırmadığını ifade etti. Daha önce Pap smear testi yapılmış kadınların hassasiyet, ciddiyet, avantaj ve motivasyon, sağlık motivasyonu alt ölçek puanları yüksekti, ancak engeller ortalama puanları düşüktü. Ciddilik, sağlık motivasyonu alt ölçekleri ile Pap smear testi yapılması arasında fark vardı ( $p=0,021$, $p=0,006)$, Sağlık Inanç Modeli Ölçeği'nin ciddiyet ve sağlık motivasyonu puanları ortalamaları daha yüksekti $(p<0,05)$. Eğitim düzeyi, çalışma durumu ve Pap testi yaptırmak arasında fark yoktu ( $>>0,05)$.

Sonuç: Pap smear testi yaptırma durumu halen orta düzeydedir ve engeller bulunmaktadır. Aile hekimleri için Pap smear testini engelleyen nedenlerin ortadan kaldırılması için girişimlerin planlanması önemli bir konudur.

Anahtar Kelimeler: Sağlık davranışı, sağlık inanışları, servikal smear

Corresponding author/iletişim kurulacak yazar: ozden.gokdemir@ieu.edu.tr

Submitted/Başvuru: 12.03.2019• Revision Requested/Revizyon Talebi: 20.04.2020 •

Last Revision Received/Son Revizyon: 11.05.2020 • Accepted/Kabul: 12.05.2020 • Published Online/Online Yayın: 19.10 .2020

(C)Telif Hakkı $2020 \mathrm{~J}$ Ist Faculty Med - Makale metnine jmed.istanbul.edu.tr web sayfasından ulaşılabilir.

(C) Copyright 2020 by J Ist Faculty Med - Available online at jmed.istanbul.edu.tr 


\section{INTRODUCTION}

Cervical cancer is one of the most common cancer types in the world and ranks fourth among the causes of death (1). In 2012, worldwide more than five hundred thousand cases of cervical cancer were newly diagnosed. According to the 2009 statistics, the cervical cancer rate is 4.5 per 100,000 women in Turkey (2).

Cervical cancer incidence increases after the age of 40 . Besides age, the other risk factors in the development of such cancer types are gene mutations, family breast/ cervical cancer history, extension in the interval between menarche and menopause, and obesity. Less serious risk factors are first sexual intercourse under the age of 16 , sexually transmitted disease history of HIV, HSV-2, genital wart, HPV, high parity, smoking, lower socioeconomic level, and use of oral contraceptives $(3,4)$.

Screening is a public health intervention provided to prevent disease development in a healthy target population. In screening, the aim is not only to find and reveal those who are sick but also to identify individuals who are likely to have the disease itself or a precursor. The most important and primary definite outcome of cervical screening is the decline of cervical cancer by the detection and treatment of cases of pre-cancer. Additionally, screening can discover the existence of cervical cancer at an early stage and increases the chances of successful treatment (5). Both breast and cervical cancers can be prevented by early diagnosis and screening programs. Besides early diagnosis and screening, it is essential to create awareness and behavioral change in society by increasing the knowledge of causes, risk factors, and symptoms. Incidences of cancer can be reduced by raising awareness of risk factors such as smoking and alcohol use, inadequate physical activity, excessive weight and amount of fat, inadequate consumption of vegetables and fruits, and Human Papilloma Virus history $(6,7)$.

According to the National Cancer Control Program, quinquennial Pap smear test among 30-65 years olds constitutes the early detection, diagnosis and screening method for cervical cancer $(8,9)$. The Pap smear test, a screening method for the early diagnosis of cervical cancer, is a part of women's healthy lifestyle and lifestyle behaviors, and increases awareness of early diagnosis and practices. These behaviors have a very important role in decreasing the number of cases, late diagnosis ratios, and boosting cancer prevention (10). Similar to developing countries, national studies show that screening frequencies are not yet at the desired levels, the regular screening rate was $39.2 \%$ in accordance with the national screening standard (11-14). Negative attitudes towards health protection are caused by misguided attitudes and beliefs (such as the belief that a healthy lifestyle and diet, and no family history of cancer means low risk) and such beliefs determine whether or not the Pap smear test is conducted $(11,15-17)$. Creating awareness about the importance of early detection is a way of encouraging women to participate in screening, which is easily done by Pap smears. Most people, however, only apply for health care when they detect a symptom. This process relies on two factors. First, patients need to identify that they have a symptom, and conclude that health professionals will be able to help health-seeking behavior. Second, this process relies upon an illness having detectable symptoms, as cancer does. Screening programs are valuable as a mean to detect signs at a time when they may not be visible to the patient, on the premise that early detection leads to better treatment success.

Considering this, it is essential to understand individuals' perceptions regarding health needs, their obstacles, decisions processes and behaviors. The Health Belief Model is often used to serve this purpose. The model consists of five main structures: perceived sensitivity, perceived seriousness, perceived advantage/motivation, health motivation and perceived obstacles. The model not only explains the screening behaviors, but also the factors that facilitate patient behaviors, patient role behaviors, and performing health behaviors (18).

Healthcare professionals should understand how cultural values and beliefs affect screening practices, and to develop programs using culturally suitable messages and convenient strategies.

In this regard, the aim was to find out which factors encourage women to take a Pap smear, and the relation between the various attitudes and belief regarding Pap smear test of patients registered with a Family Health Center.

\section{MATERIAL AND METHOD}

This cross-sectional and descriptive research was carried out to determine the knowledge, attitudes, and behaviors of 18 to 70 years old women towards cervical cancer. The participants were 266 women registered with a Family Health Center in Izmir between June-September 2015. Demographical data were collected face-to-face using questions from Cervical and Pap Smear Test Health Belief Model Scale. Data were analyzed using the SPSS 15.0 program. The Mean, standard deviation and percentage was used to evaluate participants' sociodemographic characteristics of participants. Chi-square and student's t-test were used, $p<0.05$ was accepted as significant. Approval for the study was obtained from Izmir Public Health Directorate Approvals and Dokuz Eylül University Faculty of Medicine Ethics Committee. 
Data collection tool: Champion developed this scale for breast cancer and mammography, and adapted Cervical Cancer and Pap smear test. This model was validated in various other countries (19). Guvenc et al. conducted the Turkish validity and reliability study (11). The scale consists of 35 items, and five main dimensions:

Table 1: Characteristics of participants $(n=266)$

\begin{tabular}{|c|c|c|}
\hline & $n$ & $\%$ \\
\hline $\begin{array}{l}\text { Age } \\
30-35 \\
36-40 \\
41-45 \\
46-50 \\
51 \text { and above }\end{array}$ & $\begin{array}{l}88 \\
64 \\
62 \\
28 \\
24\end{array}$ & $\begin{array}{c}33.1 \\
24.1 \\
23.3 \\
10.5 \\
9.0\end{array}$ \\
\hline $\begin{array}{l}\text { Marital status } \\
\text { Married } \\
\text { Widow/divorced }\end{array}$ & $\begin{array}{c}218 \\
48\end{array}$ & $\begin{array}{l}82.0 \\
18.0\end{array}$ \\
\hline $\begin{array}{l}\text { Employment status } \\
\text { Housewives } \\
\text { Employee/retired }\end{array}$ & $\begin{array}{c}82 \\
184\end{array}$ & $\begin{array}{l}30.8 \\
69.2\end{array}$ \\
\hline $\begin{array}{l}\text { Education level } \\
\text { Primary school } \\
\text { High school } \\
\text { College/university }\end{array}$ & $\begin{array}{l}150 \\
62 \\
54\end{array}$ & $\begin{array}{l}56.4 \\
23.3 \\
20.3\end{array}$ \\
\hline $\begin{array}{l}\text { Number of children } \\
0 \\
1-3 \\
\text { More than } 3\end{array}$ & $\begin{array}{c}36 \\
198 \\
32\end{array}$ & $\begin{array}{l}13.5 \\
74.5 \\
12.0\end{array}$ \\
\hline $\begin{array}{l}\text { Monthly income } \\
\text { Below } 500 \text { Lira } \\
500-1000 \text { Lira } \\
\text { 1001-1500 Lira } \\
\text { Above } 1500 \text { Lira }\end{array}$ & $\begin{array}{l}73 \\
70 \\
83 \\
40\end{array}$ & $\begin{array}{l}27.4 \\
26.3 \\
31.3 \\
15.0\end{array}$ \\
\hline $\begin{array}{l}\text { Age of first sexual intercourse } \\
\leq 20 \text { years } \\
>20 \text { years }\end{array}$ & $\begin{array}{l}131 \\
135\end{array}$ & $\begin{array}{l}49.2 \\
50.8\end{array}$ \\
\hline $\begin{array}{l}\text { Previous Pap smear test } \\
\text { Yes } \\
\text { No }\end{array}$ & $\begin{array}{l}157 \\
109\end{array}$ & $\begin{array}{l}59.0 \\
41.0\end{array}$ \\
\hline
\end{tabular}

sensitivity (3 items), seriousness (7 items), Pap smear advantage and motivation ( 8 items), health motivation ( 3 items), and Pap smear obstacles (14 items). This scale was assessed using a 5-Likert type scaling of "I definitely disagree" (1), "I disagree" (2), "neutral" (3), "I agree" (4), "I fully agree" (5) method ranging from 1 to 5. Each dimension of the scale was separately assessed. Higher scores indicate stronger feelings about that the scale sense. All subscales are positively related to screening behavior except for the "barriers", which have a negative association.

\section{RESULTS}

The participants' $(n=266)$ mean age was $40 \pm 8.10$ (min:30-max:70 years of age). The largest group (33.1\%) was between 30-35 years of age and married (82.0\%). Characteristics of the participants given in Table 1.

The participants' mean age of menarche was $13.24 \pm 1.2$ (min:10--max:18 years). Those with menarche age above 14 were the largest group (41.1\%). The Mean age of first sexual intercourse was $21.67 \pm 4.5$ (min:13-max: 45 years). $86.5 \%$ reported a single partner, $13.5 \%$ more than one.

Regarding Pap smear test rating and sociodemographic characteristics such as in our study, no difference was found between, education level, and employment status ( $p>0.05)$.

Scores obtained by the participants from the Health Belief Model Scale subscales are shown in Table 2.

Forty-one percent of the participants $(n=109)$ had never undergone a Pap smear test. Women who previously had a Pap smear test had high mean scores for the subscales of sensitivity, seriousness, advantage and motivation, and their health motivation mean scores for obstacle was low. Significant relations were detected between seriousness and health motivation from the Health Belief Model Scale subgroups and taking Pap smear tests $(p=0.021, p=0.006$ ) (Table 3 ).

Table 2: Participants' health belief model scale scores.

\begin{tabular}{lcccc}
\hline & Mean & SD* & Min. & Max. \\
Sensitivity & 8.59 & 2.65 & 3 & 15 \\
Seriousness & 23.63 & 7.02 & 7 & 35 \\
Advantage and motivation & 29.43 & 7.73 & 9 & 45 \\
Health motivation & 11.33 & 3.36 & 3 & 15 \\
Obstacles & 36.35 & 12.33 & 14 & 70 \\
\hline
\end{tabular}

*SD: Standard deviation 
Table 3: Participants' health belief model scale scores undergoing pap smear test or not

\begin{tabular}{lccc}
\hline Health Belief Model Scale & \multicolumn{3}{c}{ Taking Pap smear test } \\
& $\begin{array}{c}\text { Yes } \\
\text { Mean } \pm \text { SD* }\end{array}$ & $\begin{array}{c}\text { No } \\
\text { Mean } \pm \text { SD* }\end{array}$ & $\mathbf{p}$ \\
Sensitivity & $9.01 \pm 2.56$ & $7.99 \pm 2.67$ & 0,216 \\
Seriousness & $24.50 \pm 6.61$ & $22.37 \pm 7.43$ & $\mathbf{0 . 0 2 1}$ \\
Advantage and motivation & $30.46 \pm 7.44$ & $27.94 \pm 7.92$ & 0.229 \\
Health motivation & $11.78 \pm 3.12$ & $10.70 \pm 3 ., 60$ & $\mathbf{0 . 0 0 6}$ \\
Obstacles & $32.95 \pm 11.77$ & $35.17 \pm 10.82$ & 0.128 \\
\hline
\end{tabular}

*SD: Standard deviation

\section{DISCUSSION}

In studies conducted with different groups and different provinces in Turkey, Pap smear test rates were found to be generally low $(16,17,20-22)$ and slightly lower than the ratio of $59.0 \%$ detected in our study. These findings show that the percentage of applications for regular Pap smear test is below the desired levels in our country, especially when compared to rates in developed countries. One of the reasons for this case may be the obstacle caused by religious and cultural values.

In studies in literature, it was found that income and education level, health insurance and health resources, knowledge level and cultural factors have significant importance on attitudes to Pap smear test $(15,16,22-24)$. In our study, no difference was found between sociodemographic characteristics such as education level, employment status frequency of undergoing Pap smear test ( $p>0.05)$.

Another possible cause of the high proportion of women under 45 years: the similarity between the age groups in terms of smear neglect is perhaps because due to their relative youth and lack of risk perception. In addition, most of the participants were working people and generally with a lower education level. Education level may explain the lack of information about the importance of the issue, while women in employment may have difficulty in allocating time. Our study shows, in line with previous studies, that a common reason for ignoring an invitation for screening was lack of knowledge $(16,21,25,26)$.

According to the Health Belief Model, with increases in the positive perception of women regarding screening with Pap smear test, here are corresponding increases in sensitivity, seriousness, and health motivation (11). In our study, we determined that the mean scores of all sub-dimensions were at a medium level. However, no change was found in participants' sensitivity and seriousness perception ( $p>0.05$ ). However, it was detected that women with high education levels have higher seriousness score levels $(p<0.05)$, which contrasts with the results of studies done previously $(15,17,20)$.
Demirgoz determined that attitudes to Pap smear test were influenced by views on gynaecological examination, sociodemographic characteristics, Pap smear knowledge and risk perceptions related to cervical cancer, but the test's importance was not generally well-understood. A significant relationship was found between the participants' status at work, educational level and awareness of Pap smear test, on one hand, and benefit /motivation, health motivation and disability perception on the other. "Seriousness perception", however, was not affected by any variable (15).

According to the level of knowledge of regarding Pap smear, when the conditions are examined; Akyuz found that those who knows "how Pap smear test is used for gynecological cancer diagnosis and how often it should be", did the test, and the difference between them was statistically significant (17).

According to Buyukkayaci, on the subject of perceived susceptibility, however, most women expressed the belief that they were not at risk, and that cervical cancer only appeared in women older than 50 (20).

According to the Health Belief Model, as the obstacle perception increases, negative health behavior increases correspondingly. Shame, uncertainty and fear are among the reasons why women fail to take the test. The obstacle perception detected in our study is similar to other Turkish studies $(11,15,20,21,25)$.

Male practitioners applying the Pap smear test may be a significant obstacle, as one-third of the participants indicated a preference for a female doctor. Another factor that prevents application for the screening test is a feeling of being healthy. In the literature, it was observed that healthy women with no obvious symptoms tend to avoid the test (26). Only one-third of the participants in our study repeated regular health checks. Even in good general health a very common misperception was that "the test is necessary only in the presence of changes in bleeding and discharge", due perhaps, to a lack of knowledge about the issue. After eliminating this mis- 
conception, every woman may understand the risks. This research was based on finding obstacles and identified that the interaction of social and personal barriers influenced women's behavior and attendance for screening. The main barriers were found to be insufficient health education of people, absence of patient-friendly health services, different cultural and social health beliefs, also gender roles and personal factors.

\section{CONCLUSION}

Women who do not take Pap smear test due to reticence should be supported and encouraged to develop positive healthy behavior. Motivational interviews and greater patient-centeredness in the family medicine discipline are potential solutions to the obstacles for cervical cancer screening provided by women's health services (27).

Acknowledgments: The authors would like to thank the Simon Edward Mumford for language editor.

Ethics Committee Approval: This study was approved by the Dokuz Eylül University Faculty of Medicine Ethics Committee (2015 / 17-23).

Informed Consent: Written consent was obtained from the participants.

Peer Review: Externally peer-reviewed.

Author Contributions: Conception/Design of Study- O.A., Ö.G., N.Ö.; Data Acquisition- O.A., S.Y.; Data Analysis/Interpretation- O.A., Ö.G., Ü.B., N.Ö.; Drafting Manuscript- O.A., Ö.G., Ü.B., S.Y.; Critical Revision of Manuscript- Ö.G., N.Ö.; Final Approval and Accountability- O.A., Ö.G., Ü.B., S.Y., N.Ö.; Supervision- N.Ö.

Conflict of Interest: Authors declared no conflict of interest.

Financial Disclosure: Authors declared no financial support.

Teşekkür: Yazarlar, Simon Edward Mumford'a dil editörlüğünden dolayı teşekkür eder.

Etik Komite Onayı: Bu çalışma için etik komite onayı Dokuz Eylül Üniversitesi Tıp Fakültesi Etik Kurulu'ndan alınmıştır (2015 / 17-23).

Bilgilendirilmiş Onam: Katılımcılardan bilgilendirilmiş onam alınmıştır.

\section{Hakem Değerlendirmesi: Dış bağımsız.}

Yazar Katkıları: Çalışma Konsepti/Tasarım- O.A., Ö.G., N.Ö.; Veri Toplama- O.A., S.Y.; Veri Analizi/Yorumlama- O.A., Ö.G., Ü.B., N.Ö.; Yazı Taslağı- O.A., Ö.G., Ü.B., S.Y.; İçeriğin Eleştirel Incelemesi- Ö.G., N.Ö.; Son Onay ve Sorumluluk- O.A., Ö.G., Ü.B., S.Y., N.Ö.; Süpervizyon- N.Ö.

Çıkar Çatışması: Yazarlar çıkar çatışması beyan etmemişlerdir.

Finansal Destek: Yazarlar finansal destek beyan etmemişlerdir.

\section{REFERENCES}

1. Latest world cancer statistics - GLOBOCAN 2012: Estimated Cancer Incidence, Mortality and Prevalence Worldwide in 2012. The International Agency for Research on Cancer (IARC). WHO 2013. Press Release No:223. https://www.iarc. fr/wp-content/uploads/2018/07/pr223_E.pdf

2. The Ministry of Health of Turkey Health Statistics Yearbook 2014. Republic of Turkey Ministry of Health, General Directorate of Health Research: Ankara, 2015. Report No: 1009.

3. Güner H, Taşkıran Ç. Epidemiology of cervical cancer and the role of Human Papilloma Virus Turk J Obstet Gynecol 2007;4(1):11-9.

4. Gökaslan H, Uyar EE. Screening Cervical Cancer with Pap Smear. Turkish Journal of Family Practice 2004;8(3):105-10.

5. Periodic Health Examinations and Screening Tests Recommended in Family Medicine Practice. Republic of Turkey Ministry of Health Turkey, Public Health Institution: Ankara, 2015. Report No: 991.

6. Erkoç Y, Yardım N. Policies for Tackling Non-Communicable Diseases and Risk Factors in Turkey. Republic of Turkey Ministry of Health, Directorate General Primary Health Care: Ankara, 2011. Report No:809 Available from: https://www. saglikaktuel.com/d/file/ulke_raporu_baski_hali_en.pdf

7. Bebis H, Reis N, Yavan T, Bayrak D, Unal A, Bodur S. Effect of health education about cervical cancer and papanicolaou testing on the behavior, knowledge, and beliefs of Turkish women. Int J Gynecol Cancer 2012;22(8):1407-12. [CrossRef]

8. National Cancer Control Plan 2013 - 2018. Republic of Turkey Ministry of Health Turkey Public Health Institution Cancer Control Department. (Online) Available from: https://www.iccp-portal.org/system/files/plans/Ulusal_ Kanser_Kontrol_Plani_2013_2018.pdf

9. Denizli R, Sakin O, Angin AD, Cikman MS, Pirimoglu ZM. Colposcopic examination in cytology negative women who tested positive for non-16/18 HPV types. J Ist Faculty Med 2019;82(4):212-8. [CrossRef]

10. Turkey Cancer Control Programme. Republic of Turkey Ministry of Health Turkey Public Health Institution Cancer Control Department. (Online) Available from: https://www. iccp-portal.org/system/files/plans/Turkiye_Kanser_Kontrol_ Program_English.pdf

11. Guvenc G, Akyuz A, Açikel CH. Health belief model scale for cervical cancer and Pap smear test: psychometric testing. J Adv Nurs 2011;67(2):428-37. [CrossRef]

12. Champion VL. Instrument refinement for breast cancer screening behaviors. Nurs Res 1993;42(3):139-43. [CrossRef]

13. Kesic V, Markovic M, Matejic B, Topic L. Awareness of cervical cancer screening among women in Serbia. Gynecol Oncol 2005;99(3 Suppl 1):S222-S225. [CrossRef]

14. Sirovich BE, Woloshin S, Schwartz LM. Screening for cervical cancer: will women accept less? Am J Med 2005;118(2):1518. [CrossRef]

15. Bal MD. Evaluation of women having Pap smear test by Health Belief Model scale. Journal of Marmara University Institute of Health Sciences MÜSBED 2014;4(3):133-8. [CrossRef]

16. Karabulutlu O. Evaluation of the Pap smear test status of Turkish women and related factors. Asian Pac J Cancer Prev 2013;14(2):981-986. [CrossRef] 
17. Akyüz A, Güvenç G, Yavan T, Çetintürk A, Kök G. Evaluation of the Pap smear test status of women and of the factors affecting this status. Gulhane Med J 2006;48:25-29.

18. Cenesiz E, Atak N. The evaluation of the researches in the health belief model in Turkey. TAF Preventive Medicine Bulletin 2007;6(6):427-34.

19. Burak LJ, Meyer M. Using the Health Belief Model to examine and predict college women's cervical cancer screening beliefs and behavior. Health Care Women Int 1997;18(3):251-62. [CrossRef]

20. Esin MN, Bulduk S, Ardic A. Beliefs about cervical cancer screening among Turkish married women. J Cancer Educ 2011;26(3):510-5. [CrossRef]

21. Duman NB, Koçak DY, Albayrak SA, Topuz Ş, Yılmazel G. Knowledge and practices breast and cervical cancer screening among womens over age of 40 . Journal of Academic Research in Nursing 2015;1(1):30-8.

22. Gökgöz N, Aktaş D. Determination of women awareness level of cervical cancer \& conducting pap-smear test. Yıldırım Beyazıt University Journal of Nursing 2015;3(2):11-23.
23. Esencan TY. The evaluation of the behavior of women on gynecological diagnostic methods. Medical Bulletin of Zeynep Kamil 2009;40(2):63-6.

24. Markovic M, Kesic V, Topic L, Matejic B. Barriers to cervical cancer screening: a qualitative study with women in Serbia. Soc Sci Med 2005;61(12):2528-35. [CrossRef]

25. Reis N, Bebis H, Kose S, Sis A, Engin R, Yavan T. Knowledge, behavior and beliefs related to cervical cancer and screening among Turkish women. Asian Pac J Cancer Prev 2012;13(4):1463-70. [CrossRef]

26. Karaca M, Palancı Y, Aksu SR. How common is pap smear test known and performed. J Clin Obstet Gynecol 2008;18(1):228.

27. Abadi MMM, Vakilian K, Safari V. Motivational interview on having Pap test among middle-aged women - a counseling service in primary care. Fam Med Prim Care Rev 2018;2: 101-5. [CrossRef] 